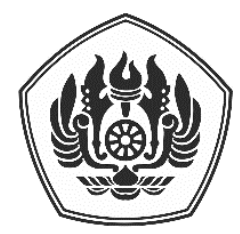

\author{
Padjadjaran Journal of International Law \\ ISSN: 2549-2152, EISSN: 2549-1296 \\ Volume 5, Number 1, January 2021
}

\title{
The Act of Abduction and Women Trafficking in Non-International Armed Conflict (NIAC): Boko Haram Case
}

\author{
Astrid Adelina, ${ }^{*}$ Nadhifa Khairunissa Ishadi ${ }^{* *}$
}

\begin{abstract}
Armed conflict situations will always have real negative implications, one of them is the attack against civilians. Civilians are considered as non-combatant, they do not participate in armed conflicts, thus they should not be targeted and attacked. One of the civilian groups who have special protection is women. But, in reality, women still frequently become the main victim. In the case of non-international armed conflict between Nigeria and Boko Haram, it is found that 2000 female students were abducted. They were sexually abused such as raped, sexual slavery, forced marriage, trafficked and ordered to commit suicide bombing. Nigeria is a state party to Additional Protocol II of the 1949 Geneva Convention as well as Rome Statute 1998. Nonetheless the crimes cannot be avoided and go unpunished. This paper highlights the analysis of the crime addressed to women from the perspective of international humanitarian law and international criminal law particularly in regards to the law enforcement. Research indicates that there is impunity which causes unwillingness of Nigeria to enforce the law against Boko Haram. Hence the international mechanism through ICC can be the best option to bring justice.
\end{abstract}

Keywords: Boko Haram, International Criminal Law, International Humanitarian Law, Non-International Armed Conflict, Women.

\section{Penculikan dan Perdagangan Perempuan dalam Konflik Bersenjata Non-Internasional: Studi Kasus Boko Haram}

\section{ABSTRAK}

Keadaan konflik bersenjata akan selalu memiliki implikasi negatif yang nyata, salah satunya terhadap pihak sipil. Pihak sipil disebut sebagai non-kombatan, yaitu orang-orang yang tidak berpartisipasi di dalam konflik bersenjata, yang berarti orang-orang tersebut bukanlah target dan tidak boleh diserang. Salah satu pihak yang mendapat perlindungan khusus adalah perempuan. Tetapi, pada kenyataannya perempuan masih sering menjadi korban utama. dalam konflik non-internasional antara Nigeria dan Boko Haram, ditemukan fakta 2000 pelajar perempuan diculik. Mereka mengalami berbagai kekerasan seksual seperti pemerkosaan, budak seks, kawin paksa, perdagangan manusia, dan bahkan untuk melakukan bom bunuh diri. Nigeria adalah negara pihak Protokol Tambahan II Konvensi Jenewa 1949 dan Statuta Roma 1998. Namun kejahatan-kejahatan tersebut tidak dapat terhindari dan tidak diadili. Tulisan ini menitikberatkan penegakan hukum terkait kejahatan terhadap perempuan dilihat dari perspektif hukum humaniter

PADJADJARAN JOURNAL OF INTERNATIONAL LAW Volume 5 Issue 1 Year 2021 [ISSN 2549-2152] [e-ISSN 2549-1296]

* Civil Servant of the Ministry of Law and Human Rights of the Republic of Indonesia, Jl. Veteran No.11, Gambir, Jakarta 10110, astrid.adel@gmail.com.

** Research Assistant at the Indonesian Centre for International Law, Jalan Imam Bonjol No. 21 Bandung, ishadinadhifa@gmail.com. 
internasional dan hukum pidana internasional. Berdasarkan penelitian, terdapat praktek impunitas yang menunjukan ketidakmauan Nigeria untuk melakukan penegakan hukum terhadap Boko Haram sebagai pelaku kejahatan tersebut. Oleh karenanya mekanisme ICC dapat merupakan pilihan terbaik untuk menegakan keadilan.

Kata Kunci: Boko Haram, Hukum Humaniter Internasional, Hukum Pidana Internasional, Konflik Bersenjata Non-Internasional, Perempuan

\section{A. INTRODUCTION}

In armed conflict situations, either international or non-international, civilians who do not participate in armed conflict often become victims, such as detained or be the object of exploitation. An example can be taken from the case in Nigeria. The conflict that took place in Nigeria's territory was between the Government of Nigeria and an organized armed group called Boko Haram.

Boko Haram is an organization founded in 2002 in North Nigeria by Mohammed Yusuf. The name Boko Haram can be translated into 'Western Education is Forbidden'. ${ }^{1}$ Mohammed Yusuf founded Boko Haram as a response to the democratic transition, nationalism, and western influence in Nigeria. ${ }^{2}$ The main purposes of Boko Haram are to apply Islamic Sharia laws in Nigeria and to expel the North Nigeria political community which he claimed has been invested by fake Muslims who conduct corruptions, to get rid of western influences in Africa, and to erase Western education including schools for girls. ${ }^{3}$ After Mohammed Yusuf got arrested and executed, Boko Haram's leader spot was taken over by Abubakar Shekau. ${ }^{4}$ After the leadership transition, the attacks conducted by Boko Haram have been more systematic and focused on the attacks on civil objects and civilians, such as schools, the Ministry of Religion of Nigeria's building, and places of worship. ${ }^{5}$

The implication that may happen towards victims that are categorized as civilians in an armed conflict is the occurrence of international crime, such as war crime. According to the opinion of Fatou Bensouda, a prosecutor of the International Criminal Court (ICC), the violations carried out by Boko Haram against the civilians, especially the kidnapping of women, are included in the act of war crimes. ${ }^{6}$ Fatou Bensouda also argues that the escalation of violence in Nigeria conducted by Boko Haram over several years may turn the ongoing conflict into a Non-International Armed Conflict (NIAC). ${ }^{7}$ This argument is also supported by the statement voiced by Jonathan Goodluck as the President of Nigeria in 2013 that stated that Nigeria is in an emergency state to combat Boko Haram. ${ }^{8}$

Simonelli, Corina (et.al.). "Boko Haram Recent Attacks", National Consortium for the Study of Terrrorism and Responses to Terrorism, 2014, pp. 1-8, https://www.start.umd.edu/pubs/STARTBackgroundReport_BokoHaramRecentAttacks_May2014_0.pdf. Accessed on $7^{\text {th }}$ of July 2020.

2 Mauro, Ryan, "Boko Haram : Nigeria's Islamist Group", Clarion Project's National Security Analyst, http://www.clarionproject.org/factsheet/boko-haram-nigerias-islamist-group\#. Accessed on $7^{\text {th }}$ of July 2020.

Simonelli, Corina (et.al), supra note 1 , at 2.

Mauro, Ryan, supra note 2, at 3.

Simonelli, Corina (et.al.), supra note 2.

Office of The Prosecutor. "Statement of the Prosecutor of the International Criminal Court, Fatou Bensouda, on the abduction of schoolgirls in Nigeria". http://www.icccpi.int/en_menus/icc/press\%20and\%20media/press\%20releases/pages/otpstatement-08-05-2014.aspx. Accessed on 26 th of May 2020.

Ibid.

8 Amnesty International Publications. Nigeria : More Than 1,500 Killed in Armed Conflict in North-Eastern Nigeria in Early 2014. 


\section{B. THE KIDNAPPING AND TRAFFICKING OF WOMEN IN NIGERIA}

Boko Haram has gone many ways to spread their beliefs, one of them by abducting civilians, especially women. One of the activities done by Boko Haram is focused on the act of kidnapping women. Since 2014, Boko Haram has kidnapped at least 2.000 girls. The women and girls who were kidnapped experienced sexual abuse, such as rape, slaves, sex slaves, suicide-bombing troopers, forced into marriages and sold to the members of Boko Haram at the price of 2000 riyal, or equivalent to 12 USD. ${ }^{9}$ Before that, Boko Haram committed a series of kidnapping, including the kidnapping of 20 women from the city of Benisheikh and Maiduguri ${ }^{10}$, the kidnapping of 218 women and children from the city of Katarko in the state of Yobe ${ }^{11}$, and the kidnapping of 100 women from the state of Adamawa. ${ }^{12}$

One of the biggest kidnappings conducted by Boko Haram was the kidnapping of students of a girls-only school in Chibok, Nigeria on April 15, 2014. ${ }^{13}$ Boko Haram was reported to have kidnapped 276 girls from their dorms who were later held captive in the forest of Sambisa, Nigeria by Boko Haram. ${ }^{14}$

The female students were to be trafficked and sent to Nigeria's neighboring countries, including Chad and Cameroon, by Boko Haram as slaves and sex slaves. To this moment, only 57 of them have successfully run away from Boko Haram. ${ }^{15}$

https://www.amnesty.org.uk/sites/default/files/niger ia_more_than_1500_killed_in_armed_conflict_0.pdf . Accessed on $7^{\text {th }}$ of July 2020.

$9 \quad$ Clarion Project Inc, "Bring Back Our Girls: One Year Later, Still Sex Slaves to Boko Haram", paragraph 4. Accessed on $17^{\text {th }}$ of January 2020

10 Human Rights Watch, "Nigeria: Boko Haram Abducts Women Recruits Children", https://www.hrw.org/news/2013/11/29/nigeriaboko-haram-abducts-women-recruits-children. Accessed on $7^{\text {th }}$ of July 2020.

11 Amnesty International Official Report. "Our Job is To Slaughter and Kill". 2015, at 71. http://www.amnistiainternacional.pt/files/Relatoriosvarios/Report_Nigeria _BokoHaram_FullReport.pdf. Accessed on $7^{\text {th }}$ of July 2020.

$12 \quad$ Ibid

13 Ibid.
Human Rights Watch interviewed 30 kidnapping victims who were taken away between mid-April 2013 to mid-April 2014, including 12 female students from Chibok who ran away from Boko Haram and 16 other witnesses. ${ }^{16}$ The victims, majorly combined of children and women, from infancy to adulthood, told that they were kidnapped from their homes, the fields they worked in, when they were fetching water or on their way to school. ${ }^{17}$ As told by the victims in the interview with Human Rights Watch, they were placed in eight different camps in the forests of Sambisa and on the hills of Gwoza (the border between Nigeria and Cameroon) ${ }^{18}$ after they were kidnapped by Boko Haram. ${ }^{19}$

According to the data provided by the UN Representative for Children and Armed Conflict in the UN Security Council assembly on January 19, 2015, more than 900.000 Nigerians, most of whom were children and women, have left their homes, more than 300 schools were vandalized and destroyed, and hundreds of children have been hurt, kidnapped, and killed by the Boko Haram. ${ }^{20}$

As the number of human trafficking done by rebel organizations, such as Boko Haram, increases, the UN Security Council argues that the continuing act of kidnapping and human trafficking that are done as a source of funding should be categorized as an international crime (war crime). ${ }^{21}$

Considering that the victims are mostly children and women, the attention given by

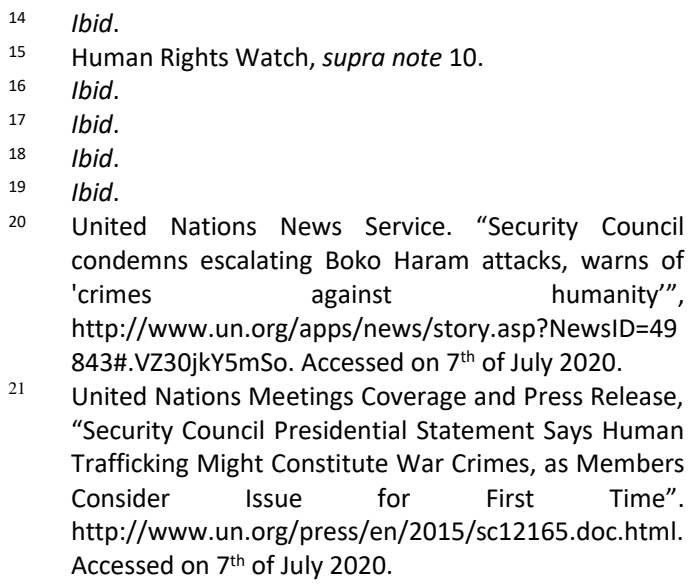


the international public is quite developed, taking into account the CRC (Convention on the Rights of the Child), CEDAW (Convention to Eliminate All Forms of Discrimination Against Women), and through the UN General Assembly Resolution No. 3318 (XXIX) dated 14 December 1974 on the Declaration on the Protection of Women and Children in Emergency and Armed Conflict. ${ }^{22}$ The declaration is filled and was formed to give attention to the victimized women and children who are part of the civilian category in a period of armed conflict.

\section{CASE REVIEW REGARDING THE ACT OF ABDUCTING AND TRAFFICKING OF WOMEN IN NIGERIA}

Nigeria is one of the parties to the Additional Protocol II (Protocol Additional to the Geneva Conventions of 12 August 1949, and Relating to the Protection of Victims of Non-International Armed Conflicts) and the 1998 Rome Statute. Nigeria has ratified Protocol II on October $10,1988,{ }^{23}$ and the 1998 Rome Statute on September 27, 2001. ${ }^{24}$ With the ratification of said conventions, Nigeria, as a State party, has the rights and obligations to carry out efforts on preventing international crimes and to enforce international law as regulated by the two conventions.

Based on the facts previously mentioned, it can be seen that in an international issue, there is often a complexity that may connect a discipline to another. The relation can be seen between humanitarian law and international criminal law, where international criminal law acts

22 Declaration on the Protection of Women and Children in Emergency and Armed Conflict. http://www2.ohchr.org/english/law/pdf/protectionw omen.pdf. Accessed on $7^{\text {th }}$ of July 2020.

23 ICRC. "Protocol I and II Additional to the Geneva Conventions".https://www.icrc.org/eng/resources/do cuments/misc/additional-protocols-1977.htm.

Accessed on $7^{\text {th }}$ of July 2020.

24 ICC. "African States Parties". http://www.icccpi.int/en_menus/asp/states\%20parties/african\%20st ates/Pages/nigeria.aspx. Accessed on $7^{\text {th }}$ of July 2020. as the enforcer of humanitarian law. ${ }^{25}$ For example, the relation visible between Article 8 of the 1998 Rome Statute on war crimes that becomes one of the absolute competencies of the International Criminal Court (ICC), regulates the protection of civilians.

Several efforts on the enforcement of humanitarian laws regarding the protection of civilians in a non-international armed conflict can be found in Article 3 of the 1949 Geneva Convention and the Additional Protocol II for non-international armed conflict. These conventions regulate the civilian's rights to protection, such as the protection of civilians and groups of civilians, attack on objects vital to civilians' needs, displacement of civilians by force, and humane treatment. ${ }^{26}$

On the other hand, international criminal law is one of the international regulations that oversees the protection of civilians through Article 5 of the 1998 Rome Statute. The article classifies international crimes into a few categories, namely genocide, crimes against humanity, and war crimes. $^{27}$

The international humanitarian law gives provision that regulates State actions as well as individual actions. One of the State obligations, in order to enforce international humanitarian law, can be done by creating national regulation that includes legal sanctions for every individual who has violated the international humanitarian law. ${ }^{28}$ As a consequence of the occurrence of war crimes, there must be a person to be held liable for the crimes that had been done. ${ }^{29}$

In international humanitarian law, the liability is addressed to the State. Article 129

25 Diantha, I Made Pasek. Hukum Pidana Internasional dalam Dinamika Pengadilan Pidana Internasional, Jakarta: Prenadamedia Group, 2014, at 20.

26 See Article 4 and Article 13 of 1977 Additional Protocol II.

See Article 5 of 1998 Rome Statute.

Ibid., at 52.

Barquero, Ray, "The New Thresholds of NonInternational Armed Conflict-- A Product of Jurisprudential Provenance?". Accessed on $7^{\text {th }}$ of July 2020. 
of 1949 Geneva Convention III regulates that State parties have the obligation to look for a party who has allegedly done or given instruction to another party regarding grave breaches that is done and brought that party to a national court, without taking into consideration their nationalities. ${ }^{30}$ Whereas in the 1998 Rome Statute, the liability of war crimes, as regulated in Article 25 of 1998 Rome Statute, can be addressed to individuals ${ }^{31}$ and, as regulated in Article 28, to the commanders $^{32}$, which means that every person who participates in war crime can be held responsible.

1. General Review based on the Perspective of International Humanitarian Law

According to Pietro Verri, "armed conflict" is a general term that includes all kinds of confrontation between several parties ${ }^{33}$, which are:

a. Between two or more States;

b. Between a State and a non-State entity;

c. Between a State and a belligerent faction; or

d. Between two ethnic groups within a State.

As time goes by, the term "laws of war" developed into "laws of armed conflict" for quite some time. It later turned into "humanitarian law" which is thought to be the most precise term. This terminology is considered to successfully represent every important action to apply principles of humanity and protect individuals from the

See Article 129 of 1949 Geneva Convention III. See Article 25 par. 31998 Rome Statute. See Article 28 letter (a) 1998 Rome Statute.

Verri, Pietro. Dictionary of the International Law of Armed Conflict, Geneva: ICRC, 1992, at. 34 - 35. https://www.icrc.org/eng/assets/files/publications/ic rc-002-0453.pdf. Accessed on $7^{\text {th }}$ of July 2020.

34 Resolution 2444 (XXIII) of the United Nations General Assembly, 19 December 1968, https://www.icrc.org/ihl/INTRO/440?OpenDocument. Accessed on $7^{\text {th }}$ of July 2020.

35 Okimoto, Keiichiro. "The Relationship Between a State and an Organised Armed Group and its Impact on the atrocities of law. The explanation that was adopted in General Assembly Resolution No. 2444 in 1968 states that the principles of humanity are needed in armed conflicts. ${ }^{34}$

\section{(a) The Definition of Non- International Armed Conflict}

The classification of conflict becomes an important thing to see which regulation is applicable and to know the scope of protection of those affected by armed conflict. ${ }^{35}$ One of the types of armed conflicts is noninternational armed conflict.

Non-international armed conflict is also known as Internal Armed Conflict. The non-international armed conflict points to a violent circumstance where a prolonged armed conflict between State forces and one or more organized armed groups, or between said groups, takes place in a State's territory. ${ }^{36}$ Regulations regarding noninternational armed conflict can be found in Article 31949 Geneva Convention on the Protection of Civilians $^{37}$ and 1977 Additional Protocol II. ${ }^{38}$

The explanation of Article 1 paragraph 1 of Additional Protocol II complements Article 3 of the 1949 Geneva Protocol and applies for noninternational armed conflict because it gives a specific explanation on the definition of non-international armed conflict completed with explanations regarding belligerents and its requirements.
Classification of Armed Conflict", Amsterdam Law Forum, vol. 10, no. 2, 2018, pp. 72-77, at 53, http://amsterdamlawforum.org/article/viewFile/322/ 495. Accessed on $3^{\text {rd }}$ of September 2020.

36 ICRC Interview with Kathleen Lawand, "Internal conflicts or other situations of violence - what is the difference for victims?", 10 December 2012, https://www.icrc.org/eng/resources/documents/inter view/2012/12-10-niac-non-international-armedconflict.htm. Accessed on $3^{\text {rd }}$ of September 2020.

37 See Article 3 of 1949 Geneva Convention.

38 See Article 1 para. 1 of 1977 Additional Protocol. 
The classification of noninternational armed conflict must be separated from circumstances, such as domestic unrest and sporadic action in a country. ${ }^{39}$ The classification on noninternational armed conflict can be found in the Judgement of Tadic Case that states that non-international armed conflict has two characteristics, namely ${ }^{40}$ :

1) Armed conflict must reach a determined intensity level

The authorized government of a State must deploy armed Forces to counter the belligerent, instead of the Police Forces in an armed conflict circumstance.

2) Non-government group(s) must be acknowledged as a party in a conflict because they are on the same side as the belligerent group.

Belligerent must be under a clear structural commando and able to do a prolonged military operation. Article 3 of the Geneva Convention explains a few rules that must be obeyed in a non-international armed conflict circumstance by every party involved, some of them are the prohibition of violence act against every individual and humane treatment in every situation on any party who is not actively participating in a conflict including sick or suspended soldiers, regardless of race, skin color, and religion.

Lindsay Moir argues in his book titled The Law of Internal Armed Conflict that non-international armed conflict has become an urgency for the international public because of several factors, ${ }^{41}$ which are: a. Non-international armed conflict has implications for the neighboring countries of the conflicted country, as there may be many civilians fleeing in-conflict areas.

b. Risk of intervention from a third country as the conflict escalates.

c. Individual as a subject of international law and international law protects every party that is not actively participating in an armed conflict.

(b) Protection of Civilians in 1977 Additional Protocol II

Other than regulating on how-to's and methods of war, international humanitarian law also regulates the protection of a certain party who is not actively participating in an armed conflict, which is the civilians. This protection was made to guarantee civilians' safety during an armed conflict. ${ }^{42}$

In a non-international armed conflict, there are a few articles that regulate the protection of civilians, which include Article 4 of Additional Protocol II on fundamental guarantees and Article 13 of Additional Protocol II on the protection of the civilian population. The commentary on Article 4 specifically explains subsidiary actions that are prohibited in a non-international armed conflict including acts of terrorism, slavery of any form, looting, and threats. ${ }^{43}$ Whereas Article 13 states that civilians that are not directly participating in hostilities must be given protection and shall not be objects of military attacks. ${ }^{44}$
ICRC Interview with Kathleen Lawand, supra note 36. ICTY, The Prosecutor v. Dusko Tadic, Judgment, IT-941-T, 7 May 1997, paras. 561-568, at 193 - 196; see also ICTY, The Prosecutor v. Fatmir Limaj, Judgment, IT-0366-T, 30 November 2005, para. 84, at 34 . http://www.icty.org/case/limaj/4. Accessed on $3^{\text {rd }}$ of September 2020.
41 Moir, Lindsay, The Law of Internal Armed Conflict, Cambridge: Cambridge University Press, 2002, at 2.

42 See the Preamble of 1949 Geneva Convention on the Protection of Civilian Persons, at 29.

43 See Article 4 of 1977 Additional Protocol II.

44 See Article 13 of 1977 Additional Protocol II. 


\section{(c) Qualification of War Crime}

War crime is a serious violation against international humanitarian law, but not all crime could be categorized as a war crime. A crime could be categorized as a war crime if it has fulfilled the elements, which are: ${ }^{45}$

(1). Armed conflict

Armed conflict (international and non-international) must occur during said act of crime.

(2). Protected persons

Victims must be under the protection of international humanitarian law (civilian, prisoners of war, hors de combat). It also applies to certain places that must have protection from international humanitarian law namely, medical facilities, cultural sites, and other public objects.

(3). Potential perpetrators

The potential perpetrator for war crime is an individual soldier, either as commander or superior. Although it does not entirely cross the possibility of actively participating civilians from committing war crimes.

(4). Nexus

The existence of a connection between the act of war crime and armed conflict circumstance allows the act of crime to be categorized as a war crime.

(5). Applicability of International Humanitarian Law

The offense that is happening must violate codified customary law or international humanitarian law that is binding for the perpetrators of crimes that happen at certain times, in order to determine which law is applicable in the trial.

(6). Gravity of Crime

The violation that happened must be serious and inflict serious effects on the victims.

(d) Classification of Belligerent

In a non-international armed conflict, parties in conflict are State and belligerent within the same area. There are three categories of rebel groups, namely ${ }^{46}$ :

(1). Rebellion

This group is considered weak since they only do acts of crime that are sporadic to the State. ${ }^{47}$ If the government of a State is able to quickly and effectively stop this group through State forces, the conflict that happened is categorized as ordinary domestic conflict. The legal impact arising from actions conducted by this group is regulated by the State's national law.

(2). Insurgency Insurgency differs from Rebellion by one additional criterion. Insurgency attacks the objects that are considered to be more substantial to the State. ${ }^{48}$

(3). Belligerent

Belligerent is considered to be the highest category of rebels. This group was born from a noninternational armed conflict. ${ }^{49}$ In other words, the existence of this group marks a higher intensity of conflict that has never happened before where its existence puts a conflict on the edge of turning it into an armed conflict.
Tadic Case, "Decision on the Defense Motion for Interlocutory on Jurisdiction", No. 94.

46 Barquero, Ray, "The New Thresholds of NonInternational Armed Conflict-- A Product of Jurisprudential Provenance?", at $6-10$, http://www.academia.edu/4663155/The_New_Thres
holds_of_Non-International_Armed_Conflict-A_Product_of_Jurisprudential_Provenance. Accessed on $3^{\text {rd }}$ of September 2020.

lbid., at 7.

Ibid., at 7-8.

Ibid., at 8-9. 
2. General Review based on the Perspective of International Criminal Law

According to Ilias Bantekas and Susan Nash, international criminal law is a fusion of two disciplines of law, which are international law and national criminal law. ${ }^{50}$ Whereas Robert Cryer argues that international criminal law is a compilation of laws that directly impose obligations on individuals and sentences the violators and is a relatively new development. ${ }^{51}$

To put it simply, international criminal law is one of the newest disciplines of law, which consists of two different branches of law, that focuses on individual responsibility for the crimes they have committed.

a. The Definition of International Crime

International criminal law regulates the crimes considered as international crimes. The definition of international crime is crimes that violate existing international regulations that refer to the individual criminal responsibility of persons concerned..$^{52}$

The elements that must be fulfilled by an international crime are: ${ }^{53}$

(1). Considered as violations against customary international regulations.

(2). Such regulations are meant to protect important values in the international

50 Bantekas, Ilias and Susan Nash. International Criminal Law. London: Cavendish Publishing Limited, 2003, at 1.

51 Cryer, Robert, An Introduction to International Law and Procedure. Cambridge: Cambridge University Press, 2007, at 1 in Diantha, I Made Pasek. Hukum Pidana Internasional dalam Dinamika Pengadilan Internasional, Jakarta : Prenadamedia Group, 2014, at 2-3.

52 Casesse, Antonio, International Criminal Law, Oxford: Oxford University Press, 2003, at 11.

53 Ibid.

54 See Article 5 of 1998 Rome Statute. community and are binding for all States and individuals.

(3). The existence of universal interest as an effort to categorize crimes.

The regulations on international crime can be found in the 1998 Rome Statute. Article 5 of the statute mentions that the four types of international crime include genocide, crimes against humanity, war crimes, and aggression. ${ }^{54}$

b. Types of International Crime

In the progress of determining the types of international crime, experts expressed various opinions. In 1973, Dautricourt wrote in his book "The Concept of International Criminal Jurisdiction - Definition and Limitation of the Subject", that there are ten crimes categorized as international crimes, such as slavery, human trafficking, and women and children trafficking. ${ }^{55}$ Bassiouni, on the other hand, claimed that there are 22 types of international crime, including war crimes and crimes against humanity. ${ }^{56}$

\section{(1) Crimes against humanity}

Crime against humanity could happen during the war and the period of peace. ${ }^{57}$ Article $6 c$ of the Nuremberg Charter states that crime against humanity consists of murder, extermination, enslavement, deportation, and other inhumane acts committed against civilians, before or during

55 Atmasasmita, Romli. Pengantar Hukum Pidana Internasional. Bandung: Refika Aditama, 2007, at $44-$ 45.

56 Bassiouni, M. Cherif. International Criminal Law, Cambridge: Transnational Publishers, Inc, 1986, at 135.

57 Akhavan, Payam. "Reconciling Crimes Against Humanity with the Laws of War Human Rights, Armed Conflict, and the Limits of Progressive Jurisprudence", Journal of International Criminal Justice, vol. 6, 2008, pp. 21-37, at 26. http://jicj.oxfordjournals.org/content/6/1/21.full.pdf. Accessed on $3^{\text {rd }}$ of September 2020. 
The Act of Abduction and Women Trafficking in Non-International Armed Conflict (NIAC): Boko Haram Case

the war; or persecutions based on political, racial, or religious grounds in connection with any crime within the jurisdiction of the Tribunal, whether or not violating the domestic law where the crimes took place in. ${ }^{58}$

A similar definition of the crimes against humanity can also be found in Article 7 of the 1998 Rome Statute. But this definition differs from the previous one as it adds a new, specific element regarding the crimes against humanity which states that crimes against humanity must include a series of attacks that is widespread or systematic. ${ }^{59}$

\section{(2) War crimes}

Article 8 of the 1998 Rome Statute states that war crimes are a serious violation of the law and customs applied in international and noninternational armed conflicts. ${ }^{60}$ The regulation on non-international armed conflict can be found in Article 8 letter c and e of the 1998 Rome Statute. ${ }^{61}$

\section{CRIMES AGAINST HUMANITY AND WAR CRIMES CONDUCTED BY BOKO HARAM}

The international humanitarian law provides provisions that regulate State actions and individual behaviors. One of the State's obligations to enforce international humanitarian law is by creating national regulations completed with legal sanctions for every perpetrator that violates the international humanitarian law. ${ }^{62}$ As a consequence of the occurrence of a war

58 International Military Tribunal (Nuremberg) Judgment $\begin{array}{llll}\text { of } & 1 & \text { October } & 1946 .\end{array}$ http://crimeofaggression.info/documents/6/1946_Nu remberg_Judgement.pdf. Accessed on $3^{\text {rd }}$ of September 2020.

59 See Article 7 of 1998 Rome Statute.

60 IHL Database. "Rule 156 : Definition of War Crimes". https://www.icrc.org/customary-

ihl/eng/docs/v1_rul_rule156. Accessed on $15^{\text {th }}$ of September 2020 crime, individual criminal responsibility is required of the perpetrator of war crimes. ${ }^{63}$

In international humanitarian law, the form of responsibility is addressed to the State, as regulated in Article 129 of 1949 Geneva Convention III. The article regulates that States have the responsibility to look for parties who allegedly have committed or instructed other parties to commit grave breaches that brought said parties to the national Court, without taking into consideration the nationality that they possess. ${ }^{64}$ Whilst the 1998 Rome Statute regulates that the responsibility of a war crime, according to Article 25, is addressed to individuals ${ }^{65}$, and, according to Article 28, to commanders ${ }^{66}$, which means that every individual who commits war crime can be held responsible.

1. The Crimes of Boko Haram linked to the Qualification of War Crimes According to International Humanitarian Law. ${ }^{67}$

\section{(a) Armed Conflict}

Boko Haram has conducted various crimes, such as murdering civilians, kidnapping and trafficking civilians, destroying public objects, and many more in several states in the northern part of Nigeria. ${ }^{68}$ Consequently, the government of Nigeria had to deploy Nigerian armed Forces and Joint Task Force (JTF) to stop Boko Haram from committing crimes. ${ }^{69}$ Actions done by Boko Haram have triggered the occurrence of non-international armed conflict.

\section{(b) Protected Persons}

In this case, Boko Haram has turned civilian objects, such as places of

\footnotetext{
See Article 8 letter c and e of 1998 Rome Statute.

Ibid., at 52

Barquero, Ray, supra note 46.

See Article 129 of 1949 Geneva Convention III

See Article 25 para. 3 of 1998 Rome Statute.

See Article 28 letter a of 1998 Rome Statute.

Tadic Case, "Decision on the Defence Motion for Interlocutory on Jurisdiction", No. 94.

Amnesty International, supra note 8.

Human Rights Watch, supra note 10.
} 
worship and a UN Building into a place to spread terror. Other than that, Boko Haram mainly targeted civilians in their attacks, for example, the killing that happened in the state of Borno which killed more or less 300 people. ${ }^{70}$ To add, Boko Haram also kidnapped and trafficked 276 female students from Chibok. $^{71}$ In international humanitarian law, civilian and civil objects are under the protection of international humanitarian law so that they must not be targets of attacks because they are not military objects. $^{72}$

\section{(c) Potential Perpetrators}

Boko Haram has thousands of members under the leadership of their commander, Abubakar Shekau. Abubakar Shekau oftentimes claims attacks happened in Nigeria, one of them is of a video that shows the kidnapping of 276 female students in Chibok, as Boko Haram's doings. ${ }^{73}$ Looking at the structure of the Boko Haram organization, Abubakar Shekau is the person that can be held responsible for the crimes done by Boko Haram as the chain of commands is visibly seen to be led by him.

\section{(d) Nexus}

In this case, other than doing the crimes categorized as crimes against humanity and war crimes, Boko Haram also has done other types of crime, which is abducting and trafficking women. ${ }^{74}$ If the crime of abducting and trafficking women is being linked to the non-

Simonelli, Corina, supra note 1.

Muscati, Samer, "Those Terrible Weeks in Their Camp", Human Rights Watch, 2014. https://www.hrw.org/report/2014/10/27/thoseterrible-weeks-their-camp/boko-haram-violenceagainst-women-and-girls. Accessed on $15^{\text {th }}$ of September 2020

Article 3 of Geneva Convention. international armed circumstance that's happening in Nigeria, there is a correlation between the two because the action is being targeted against civilians (women and children), whereas civilians are under the protection of international humanitarian law.

(e) Applicability of International Humanitarian Law

The crimes done by Boko Haram in Nigeria have fulfilled the classification of a non-international armed conflict, thus humanitarian law is applicable in this situation. The crimes done by Boko Haram violate provisions in Article 3 of the 1949 Geneva Convention and 1977 Additional Protocol II.

\section{(f) Gravity of Crime}

The crime of abducting and trafficking women done by Boko Haram is considered to have fulfilled the gravity of crime of a war crime. The abducting and trafficking of women have horrible implications on the victims, especially those who are not able to run away. The crime also has bad implications for the public in general since there are still, more or less, 200 female students that couldn't be saved yet, that badly affect their families and people around them.

Analyzing the Boko Haram Case, seen from the condition and urgency that Nigeria has over the existence of Boko Haram, it can be concluded that Boko Haram can be categorized as belligerent. Belligerent is the highest type of group of rebels. ${ }^{75}$ Requirements

73 Smith, Mike, "FACTSHEET: Explaining Nigeria's Boko Haram and its violent insurgency", 2014, para. 10, https://africacheck.org/factsheets/factsheetexplaining-nigerias-boko-haram-and-its-violentinsurgency/. Accessed on $15^{\text {th }}$ of September 2020. Ibid.

75 Gupta, Rashi Shailesh. "Recognition Of Insurgents and Belligerent Organisations in International Law", India: Nirma University - Institute of Law, 2014. 
that must be fulfilled by a rebel group to reach the status of belligerent are: ${ }^{76}$

(a) Must be in a country experiencing armed conflict.

(b) Rebel groups must occupy the majority of the national territory of a country.

(c) Armed conflict must follow the laws of war and there is an organized armed group that has a person in charge.

(d) A certain situation that makes another country defines or acknowledges the group as a belligerent.

\section{The Crimes of Boko Haram linked to Crimes against Humanity}

a. Elements of the Actions as part of the Attack.

Article 7 of the Rome Statute states certain acts of crimes that can be included in the category of Crimes Against Humanity. If linked to this element, the crime that's done must be a "part" of the attack. ${ }^{77}$ About the action can also be categorized as the "attack" itself, ${ }^{78}$ for example, the mass murder of civilians is enough to be categorized as an attack against civilians. So that other actions done during the mass murder do not have to be proven.

According to Article 7 of the 1998 Rome Statute, an "attack" does not have to be a military attack as regulated by international humanitarian law. ${ }^{79}$ The "attack" does not need to correlate with an Armed Force or an armed conflict. ${ }^{80}$

If linking the first element to the Boko Haram case, it can be seen that the crimes done by Boko Haram have fulfilled the first

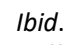
Statute of the International Criminal Court: Observers' Notes, Article by Article", Germany: Nomos Verlagsgesellschaft Baden - Baden, 1999, at 124. element. This can be seen from the killing of 185 civilians in the borders of Kano and the massacre of 300 civilians in one of the cities in the state of Borno.

b. Element of Widespread or Systematic.

To differentiate crimes against humanity from other international crimes, the element of "widespread" or "systematic" must be fulfilled. The element of widespread is one of the elements needed to be fulfilled in order to differentiate crimes against humanity from other types of crime. The element of "widespread" points to the number of victims. ${ }^{81}$ Other than that, the element of "widespread" can also mean that the attacks were done massively, on a big scale, frequently, and quite collectively in a serious manner. ${ }^{82}$ The element of systematic refers to a pattern or methodical planning, in the form of an organized pattern and follows a regular pattern. ${ }^{83}$

If the second element is being linked to the Boko Haram case, the series of attacks done by Boko Haram since 2009, including the murder of more than 5.000 civilians in several states in Nigeria, especially the northern part of Nigeria. The main targeted cities by Boko Haram include Borno, Yobe, Adamawa, Izghe, and Gamboru Ngala. ${ }^{84}$ The pattern of attack done by Boko Haram has similarities that include murdering, abducting, destroying civilian, public objects,

Ibid.

Ibid., at 125 .

Ibid., at 126 .

Ibid.

Ibid.

Amnesty International, supra note 8. 
massacring, and pillaging civilians' property. ${ }^{85}$

c. Element of Attack on Civilians.

The attack on civilians is another element that must be fulfilled to count a crime as a crime against humanity. ${ }^{86}$ The attack does not require the entire civil population, entity, or area of a state's territory as a subject of attack. ${ }^{87}$ The term "civilian" means every person that is not actively participating in wars or those who are no longer actively participating, such as armed force members who have laid down their arms and hors de combat due to illness, wounds, detention, and other reasons. ${ }^{88}$

If linked to the third element, the majority of Boko Haram attacks, including murder, suicide bombing, and looting, are indeed intentionally aimed against civilians.

d. Element of Knowledge of Impending Attack.

The perpetrators of crime must know and be conscious of the nature of the attacks conducted by them as systematic and widely spread against the civilians. ${ }^{89}$

By linking this element to the Boko Haram case, it can be seen that Boko Haram fulfills the element of 'knowing' based on the statement expressed by Boko Haram's spokesman, Abu Qaqa, on the attack on UN Headquarters in Abuja. Abu Qaqa claimed responsibility for the attack on UN Headquarters as the UN is considered to represent the Nigerian Government. ${ }^{90}$ Based on the said statement, it can be said that Boko Haram's members were

Triffterer, Otto (ed), supra note 77.

Ibid.

Ibid.

Ibid.

Ibid. aware of the systematic attack on the UN Headquarters in Abuja.

3. Boko Haram act as war crimes

Elements of war crimes conducted by Boko Haram can be seen from:

a. Serious Violations of Article 3 of 1949 Geneva Convention.

Non-international armed conflict has two forms which are armed conflict between Government Armed Forces and organized armed groups, and between two organized armed groups. ${ }^{91}$ In a situation where one of the types of armed conflict is occurring, there must be serious violations against protected fundamental values, including those codified in Article 3 of the Geneva Convention, and said violations must result in serious consequences that affect the victims. ${ }^{92}$

b. Provision on Protected Persons.

Regarding the parties that are given protection during an armed conflict, Article 8 of the Rome Statute does not provide a detailed explanation on who the parties are but according to the commentary of Article 3 of the Geneva Convention, the protected parties include civilians who are not participating in an armed conflict circumstance, members of the Armed Forces who have laid down their arms, and hors de combat. ${ }^{93}$

c. Types of War Crimes in a NonInternational Armed Conflict based on Article 8 letter (e).

Even though it must be the last resort in a dispute settlement and is not suggested to be used as a tool for conflict resolution, war is a condition that cannot be avoided.

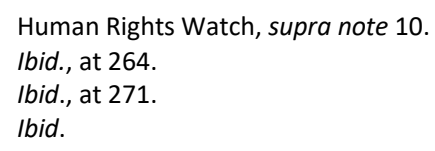


Since the 1990s, armed conflict has been happening at a noninternational level. However, it does not rule out the possibility that in an armed conflict, there may occur an offense that results in large casualties.

The regulation on war crimes occurring in a non-international armed conflict is available in Article 8 paragraph 2 letter (c) and (e) of the 1998 Rome Statute. Looking at the crimes committed by Boko Haram in a non-international armed conflict, Boko Haram allegedly has done a few types of war crimes in Nigeria, namely:

a. War Crimes based on Article 8 paragraph 2 letter (c).

(1) Cruel Treatment

Cruel treatment refers to actions that cause serious implications on a person's psychic, physical suffering, or wounds resulting from serious attacks against one's dignity. ${ }^{94}$ Based on the data provided by the witnesses, Boko Haram soldiers have committed actions that cause prolonged traumas on women and girls who were successfully ran away from Boko Haram's camps.

b. War Crimes based on Article 8 paragraph 2 letter (e).

(1) Intentional attack on civilian population or individuals that are not participating in wars.

Civilians are the most frequently attacked party in an armed conflict, whether it is intentional or unintentional. Based on the data obtained, Boko Haram intentionally attacks civilians in various ways, one of them is by abducting and trafficking women.

\section{E. LAW ENFORCEMENT MEASURES ON CRIMES COMMITTED BY BOKO HARAM ACCORDING TO INTERNATIONAL HUMANITARIAN LAW AND INTERNATIONAL CRIMINAL LAW}

The crimes that had been committed in armed conflict situations inflict harm on the innocent party. Which results in the parties concerned in an armed conflict having the responsibility to face serious consequences. These consequences must be accounted for as a form of implementation and enforcement of international law. Both humanitarian law and international criminal law uphold a form of accountability for the occurrence of international crimes, such as crimes against humanity and war crimes.

The difference between the two disciplines can be seen on the subjects. International humanitarian law emphasizes more on the form of responsibility for a crime, while international criminal law prioritizes individual responsibility for the occurrence of a crime. ${ }^{95}$ To analyze Boko Haram Case from the perspective of law enforcement mechanisms, it is necessary to know relevant law mechanisms applicable for a certain type of crimes and the scope of the law that regulates, namely:

1. The Enforcement Mechanisms of International Humanitarian Law and International Criminal Law and the Accountability for the Crimes conducted by Boko Haram.

Every crime conducted within the territory of a State must be accounted for by the perpetrators through a judicial mechanism. International humanitarian law and international criminal law oblige every country to enforce laws against perpetrators in a national court first. But no law prohibits criminal cases to be brought to an international court.

Nigeria is a state party to the Additional Protocol II and 1998 Rome 
Statute. The conflict that's happening between the Nigerian Government and Boko Haram has existed since 2009. Based on that information, the Boko Haram case can be brought to the International Court of Justice (ICC) as it has fulfilled the requirements provided in the 1998 Rome Statute.

According to Article 13 of the 1998 Rome Statute, the law can be enforced on the occurrence of international crimes through several mechanisms, namely ${ }^{96}$ :

(1). A situation submitted by a State Party of 1998 Rome Statute.

(2). A situation submitted by the UN Security Council based on Article VII of the UN Charter.

(3). A situation submitted by the Prosecutor.

Referring to the data obtained, the UN Security Council has declared Boko Haram as a serious threat to Nigeria. ${ }^{97}$ But, to this day, the UN Security Council still relies on the regional cooperation of African nations to stop the movement of Boko Haram. ${ }^{98}$ As a State party to the 1949 Geneva Convention, 1977 Additional Protocol II, and the 1998 Rome Statute, the Prosecutor may first conduct investigation needed in Nigeria to determine what type of crime has taken place there in accordance with the competence of ICC in Article 13 paragraph c.

Since 2009, the Government of Nigeria has conducted efforts in order to investigate and punish people allegedly involved in Boko Haram's attacks. ${ }^{99}$ However, the law enforcement process is filled with

See Article 13 of 1998 Rome Statute.

United Nations Meeting Coverage and Press Release, "Security Council Presidential Statement Condemns Boko Haram Attacks, Supports Joint Strategy to Combat Terrorist Group's Threats", http://www.un.org/press/en/2015/sc11983.doc.htm. Accessed $25^{\text {th }}$ September 2020.

98 United Nations Meeting Coverage and Press Release, "Security Council condemns Boko Haram violence, backs regional efforts to counter ongoing attacks", various problems, such as the unclear whereabouts of the majority of the parties detained by Nigeria, the fate of the detainees in military detention facilities for a long time without trial, the delayed court trials, the lack of legal representation for the accused, and the absence of the Prosecutor. ${ }^{100}$

The other reason that supports the exercise of direct enforcement mechanism as the most appropriate way is the fact that there are also violations conducted by Nigerian armed Forces during the investigation against alleged members of Boko Haram, such as the killing of 8.000 civilians, torture, and forced disappearance. ${ }^{101}$ At least nine members of the Nigerian Armed Forces are deemed responsible for the violations, namely General Azubuike Ihejirika as the Head of Armed Forces, Admiral Ola Sa'ad Ibrahim as the Head of Defense, Major General John A.H. Ewansiha, and Brigadier General Austin O. Edokpayi.

The authority of the Nigerian Government to bring the Boko Haram case to the ICC is linked to the admissibility of ICC as regulated in Article 17. ${ }^{102}$ Considering that the ICC has complementary nature which means the ICC can only try a perpetrator of a country if the country in question is unable or unwilling to do so. Based on Article 17 par. 2 of the 1998 Rome Statute, it said that Nigeria has shown unwillingness and inconsistency in conducting a proper and correct trial.

http://www.un.org/apps/news/story.asp?NewsID=51 513\#.Vx-UonotHYg. Accessed on 24 $4^{\text {th }}$ September 2020. Ibid.

101 Amnesty International, "Nigeria: Senior members of military must be investigated for war crimes", https://www.amnesty.org/en/latest/news/2015/06/n igeria-senior-members-of-military-must-beinvestigated-for-war-crimes/. Accessed on $24^{\text {th }}$ September 2020.

102 See Article 17 of 1998 Rome Statute. 


\section{Criminal Responsibility of the Leader of Boko Haram and the Leader of Nigerian Armed Forces}

Article 25 and 28 of 1998 Rome Statute regulates the forms of criminal responsibility, such as:

(1) Individual responsibility (Article 25)

(2) Commander's responsibility (Article 28)

(3) Other superiors' responsibility (Article 28)

The three forms of responsibility have differences between one another. Individual responsibility arises if a person is proved to have "conducted" a crime that violates the law as it occurs. ${ }^{103}$ This type of responsibility appears when an individual is proved to have 'directly conducted a crime with another person or conducted a crime through another person'. An individual who 'instructs' or 'pays' or 'causes' another person to conduct a crime is directly responsible for the crime. ${ }^{104}$ Commander's responsibility or other Superior's responsibility is a type of responsibility addressed to the commander or other superiors that arises when there are crimes committed by their subordinates whom they have control over. If it can be proved that they 'knew or should have known' about such crimes and 'failed to take all necessary and reasonable measures to prevent or repress their commission or to submit the matter to the competent authorities for investigation and prosecution.' Commander's responsibility is said to be an indirect responsibility due to its lighter characteristic compared to individual responsibility, as it reflects a form of negligence. ${ }^{105}$

Referring to the data obtained, the leader of Boko Haram, could be subjected to criminal responsibility. The

Komnas Perempuan, "Buku II: Hukum Pidana
Internasional dan Perempuan", Publikasi Komnas Perempuan, Jakarta, 2006, at 24. leader of Boko Haram, Abubakar Shekau, could be subjected to individual responsibility. Abubakar Shekau, who allegedly has done crimes against humanity and war crimes, could be subjected to direct criminal responsibility as his actions reflect the individual act of ordering other people to conduct a crime, instructing other people, and causing the occurrence of a crime.

In order to create law enforcement that is fair and thorough, the mechanism of law enforcement conducted by the ICC is the best way to prosecute the perpetrators of the crimes happening in Nigeria. Since there can be found traces of unwillingness from the Nigerian party to try said perpetrators in their national court fairly and appropriately, the law enforcement conducted by the ICC may rule out the impunity owned by the Heads of Nigerian Armed Forces. The problem that is being faced by Nigeria includes the fact that some members of the Nigerian Government itself have allegedly been involved in a similar crime as the crime conducted by Boko Haram. This situation makes it difficult for appropriate and fair law enforcement and court to happen in Nigeria regarding all the crimes that have happened and conducted by both sides unless the UN Security Council issues a resolution to carry out further investigations on the armed conflicts happening in Nigeria to later be brought to the ICC.

\section{E. CONCLUSION}

Based on the previous explanation, the existence of a link between crimes mentioned above and the ongoing armed conflict situation, acts of kidnapping and trafficking of women, although not directly regulated in Article 3 of Geneva Convention

104 Ibid.

105 Ibid. 
and Additional Protocol II, have violated the provisions of humanitarian law. Boko Haram has also conducted crimes against humanity and war crimes as regulated by the provisions under Article 7 and Article 8 of the 1998 Rome Statute, where such crimes were intentionally directed at civilians.

The international law prioritizes the enforcement of law over the occurrence of international crimes through indirect law enforcement through national court. However, as the element of unwillingness was shown by the Nigerian party, completed with impunity glued to authorized, concerned military officials that allegedly have done crimes similar to those done by Boko Haram, the use of direct law enforcement by the ICC seems to be the most appropriate thing to do.

\section{REFERENCE}

\section{Books}

Ambarwati (et. al.). Hukum Humaniter Internasional dalam Studi Hubungan Internasional. Jakarta: PT Rajagrafindo Persada, 2009.

Amnesty International Publications. Nigeria : More Than 1,500 Killed in Armed Conflict in North-Eastern Nigeria in Early 2014. London: Amnesty International Publications, 2014.

Atmasasmita, Romli. Pengantar Hukum Pidana Internasional. Bandung: Refika Aditama, 2000.

Bantekas, Ilias \& Nash, Susan. International Criminal Law. London: Cavendish Publishing Limited, 2003.

Bassiouni, M. Cherif. International Criminal Law 3rd Edition. Leiden: Koninklijke Brill NV, 2011.

Casesse, Antonio. The Oxford Companion to International Criminal Justice. Oxford: Oxford University Press, 2009.

Cassese, Antonio. International Criminal Law. Oxford: Oxford University Press, 2003.
Diantha, I Made Pasek. Hukum Pidana Internasional dalam Dinamika Pengadilan Pidana Internasional, Jakarta: PRENADAMEDIA GROUP, 2014.

Komnas Perempuan. Buku II: Hukum Pidana Internasional dan Perempuan. Jakarta: Publikasi Komnas Perempuan, 2006.

Moir, Lindsay. The Law of Internal Armed Conflict. Cambridge: Cambridge University Press, 2002.

Permanasari, Arlina (et. al.). Pengantar Hukum Humaniter. Jakarta: International Committee of the Red Cross, 1999.

Triffterer, Otto (ed). Commentary on the Rome Statute of the International Criminal Court: Observers' Notes, Article by Article. Baden-Baden, Germany: Nomos Verlagsgesellschaft, 1999.

\section{Journals}

Amnesty International. "Nigeria: Senior members of the military must be investigated for war crimes". Amnesty International Publications, 03 June 2015.

Barquero, Ray. "The New Thresholds of Non-International Armed Conflict-- A Product of Jurisprudential Provenance?".

ICC (International Criminal Court). Booklet "Victims Before the International Criminal Court". Box. 4 "Who is a Victim for ICC?".

Gupta, Rashi Shailesh. "Recognition of Insurgents and Belligerent Organisations in International Law". Nirma University - Institute of Law, India, 2014.

Okimoto, Keiichiro. "The Relationship Between a State and an Organised Armed Group and its Impact on the Classification of Armed Conflict", Amsterdam Law Forum, 2013. 
Mauro, Ryan, Clarion Project's National Security Analyst. "Boko Haram: Nigeria's Islamist Group", 2013.

\section{Other Documents}

Amnesty International. "Nigeria: Abducted women and girls forced to join Boko Haram attacks". 14 April 2014. https://www.amnesty.org/en/latest/ news/2015/04/nigeria-abductedwomen-and-girls-forced-to-joinboko-haram-attacks/.

Amnesty International Official Report, "Our Job is To Slaughter and Kill". 2015, http://www.amnistiainternacional.pt/files/Relatoriosvario s/Report_Nigeria_BokoHaram_FullRe port.pdf.

Human Rights Watch. "Nigeria: Boko Haram Abducts Women, Recruits Children". $29 \quad$ November 2013. https://www.hrw.org/news/2013/11 /29/nigeria-boko-haram-abductswomen-recruits-children.

Human Rights Watch Report. "Spiraling Violence - Boko Haram Attacks and Security Force Abuses in Nigeria". 11 October

2012. https://www.hrw.org/report/2012/1 0/11/spiraling-violence/boko-haramattacks-and-security-force-abusesnigeria.

International Committee of The Red Cross, "Customary IHL Rule 156: Definition of War Crimes". https://www.icrc.org/customaryihl/eng/docs/v1_rul_rule156.

International Committee of The Red Cross Interview with Kathleen Lawand. "Internal conflicts or other situations of violence - what is the difference for victims?". 10 December 2012. https://www.icrc.org/eng/resources/ documents/interview/2012/12-10- niac-non-international-armedconflict.htm.

International Criminal Tribunal for Yugoslavia, "The Prosecutor v. Dusko Tadic", Judgment, IT-94-1-T, 7 May 1997.

http://www.icty.org/case/limaj/4.

Office of The Prosecutor. "Statement of the Prosecutor of the International Criminal Court, Fatou Bensouda, on the abduction of schoolgirls in Nigeria". ICC. http://www.icccpi.int/en_menus/icc/press\%20and\% 20media/press\%20releases/pages/ot p-statement-08-05-2014.aspx.

Simonelli, Corina (et. al.). "Boko Haram Recent Attacks", National Consortium for the Study of Terrorism and Responses to Terrorism.

https://www.start.umd.edu/pubs/ST ARTBackgroundReport_BokoHaramR ecentAttacks_May2014_0.pdf.

United Nations Documents on Resolution no. 3074 concerning Principles of International Cooperation in the Detection, Arrest, Extradition and Punishment of Persons Guilty of War Crimes and Crimes Against Humanity. http://www.un.org/documents/ga/r es/28/ares28.htm.

United Nations MeetingsCoverage and Press Release. "Security Council Presidential Statement Says Human Trafficking Might Constitute War Crimes, as Members Consider Issue for First Time". http://www.un.org/apps/news/story .asp?NewsID=49843\#.VfZkNpc5mSp.

\section{Legal Documents}

1949 Geneva Convention.

1977 Additional Protocol I

1977 Additional Protocol II 1998 Rome Statute. 